\title{
Pengaruh Hailullah (Tidur Pagi Setelah Subuh) terhadap Tingkat Stres Mahasiswa
}

\author{
Siti Miftahul Jannah ${ }^{1)}$, Rizki Gatot Febrian ${ }^{2)}$, Cindy Desy Ariyani ${ }^{3)}$, Darosy Endah \\ Hyoscyamina $^{4)}$ \\ ${ }^{1}$ Jurusan Psikologi, Fakultas Psikologi, Universitas Diponegoro, Email: dcmita4@gmail.com \\ ${ }^{2}$ Jurusan Kedokteran, Fakultas Kedokteran, Universitas Diponegoro, Email: gatot.8c24@gmail.com \\ ${ }^{3}$ Jurusan Ilmu Gizi, Fakultas Kedokteran, Universitas Diponegoro, Email: cindydesy.03@gmail.com \\ ${ }^{4}$ Dosen Jurusan Psikologi, Fakultas Psikologi, Universitas Diponegoro, Email: \\ bundarosyendah@gmail.com
}

\begin{abstract}
Abstrak
Penelitian terdahulu menyebutkan banyaknya kegiatan mahasiswa penyebab stres yang ditandai dengan perubahan pola tidur. Banyak mahasiswa yang melakukan aktivitas malam hari dan akhirnya tertidur pada pagi hari setelah subuh. Belum banyak penelitian yang mengungkap pengaruh tidur pagi setelah subuh terhadap (hailulah) tingkat stres mahasiswa. Peneliti melakukan wawancara terhadap 30 mahasiswa mengenai efek yang dirasakan setelah melakukan hailulah. Penelitian ini bertujuan untuk mengetahui tingkat stres mahasiswa yang melakukan hailulah dengan mahasiswa yang tidak melakukan hailulah. Penelitian ini adalah penelitian eksperimental dengan desain penelitian menggunakan posttest only control group design. Teknik sampling yang digunakan adalah purposive sampling. Dalam pemilihan subjek menggunakan screening berupa pretest menggunakan skala DASS21. Penelitian ini melibatkan 56 orang yang dibagi menjadi 2 kelompok (kontrol dan eksperimen). Data dianalisis menggunakan uji Mann-Whitney. Hasil perbandingan posttest kelompok kontrol dan eksperimen pada depresi 30,48 dan 26,52; pada kecemasan, 32,73 dan 24,27; pada stres, 30,75 dan 26,25. Hasil yang didapat dari penelitian ini, menunjukkan bahwa mahasiswa yang memiliki kebiasaan melakukan hailulah memiliki tingkat kecemasan lebih tinggi daripada mahasiswa yang tidak melakukan kebiasaan hailulah. Selain itu, orang yang tidak memiliki kebiasaan hailulah memiliki tingkat depresi dan stres yang lebih rendah dibandingkan orang yang memiliki kebiasaan hailulah. Dalam penelitian selanjutnya, diharapkan dapat menggunakan variabel yang menyangkut bidang ilmu lain dan menggunakan variabel kontrol yang lebih spesifik sehingga dihasilkan data yang lebih valid karena tidak dipengaruhi oleh faktor-faktor lain yang berbeda.
\end{abstract}

Kata Kunci: hailulah, depresi, kecemasan, stres 


\section{Pendahuluan}

Stres adalah suatu keadaan yang muncul akibat ketidakseimbangan antara tekanan yang dihadapi individu dan kemampuan untuk menghadapi (Evanjeli, 2012). Stres dapat terjadi kepada siapa saja termasuk mahasiswa. Dalam banyak penelitian yang telah dilakukan diketahui bahwa pada semester 1 maupun 2 (tahun pertama) dan semester 7 maupun 8 (tahun terakhir), mahasiswa cenderung mengalami stres (Zuama, 2014). Pemicu stres mahasiswa diantaranya adalah IPK rendah, peraturan akademik di perguruan tinggi, deadline tugas, hambatan penyelesaian tugas akhir, tuntutan orang tua untuk berprestasi, keinginan meraih predikat Cumlaude, tuntutan untuk segera menyelesaikan kuliah dan banyak kegiatan organisasi yang ikuti sehingga kurang memiliki waktu istirahat, jarang masuk kelas dan kurang aktif mengikuti pembelajaran di kelas. Stres yang dialami mahasiswa ini kemudian sering di sebut stres akademik. Stres akademik dapat mempengaruhi kondisi tingkah laku dan sosial berupa mengurangi interaksi dengan teman, pola makan dan pola tidur yang terganggu serta peningkatan frekuensi merokok (Sarfriyanda, Karim and Dewi, 2015).

Aktivis mahasiswa kesulitan dalam mengontrol waktu. Sebagian besar aktivis mahasiswa akan memilih tawaran teman untuk berkumpul apabila kegiatannya mengasyikan dan kurang menahan diri terhadap gangguan telepon atau sosial media (Barr and Harta, 2014). Pada umumnya, sebagian besar mahasiswa yang memilih tawaran teman tersebut akan larut terhadap kegiatannya pada malam hari yang pada akhirnya lalai akan tugas lainnya. Sementara itu, tugastugas lain dituntut harus selesai tepat pada waktunya. Kemudian, mahasiswa memilih untuk mengerjakan tugas lain pada tengah malam atau bahkan dini hari.

Berdasarkan studi pendahuluan, dalam 15 orang mahasiswa yang diwawancara, hanya 8 orang yang memiliki jam tidur yang cukup, dan terdapat 7 orang sisanya mempunyai kebiasaan tidur di atas jam 12 malam, dan rata-rata kebiasaan para mahasiswa yang menyebabkan mereka tidur larut malam beragam, kebanyakan dari mereka sering memainkan handphone dan laptop sebelum tidur. Padahal di 
PSISULA: Prosiding Berkala Psikologi

Vol. 1, 2019

E-ISSN: 2715-002X

pagi harinya mereka harus terbangun untuk melakukan aktifitas perkuliahan (Sarfriyanda, Karim and Dewi, 2015). Namun, banyak pula mahasiswa yang memilih tidur pada pagi hari setelah Subuh sebelum berangkat kuliah.

Tidur pagi dalam perspektif Islam memiliki hukum makruh sebagaimana dijelaskan oleh Ibnul Qayyim rahimahullah,

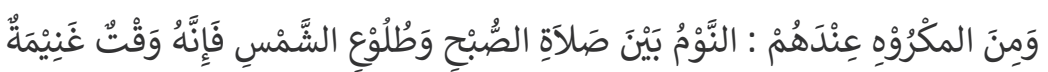

Artinya : "Di antara hal yang makruh menurut para ulama adalah tidur setelah Sholat Subuh hingga matahari terbit karena waktu tersebut adalah waktu memanen ghonimah (waktu meraih kebaikan yang banyak)." (Madarijus Salikin, 1:369).

Peneliti juga melakukan wawancara terhadap 30 mahasiswa mengenai efek yang dirasakan setelah melakukan hailulah. Dari hasil wawancara, 90\% dari mahasiswa yang melakukan hailulah merasakan hal-hal yang terkait stres, seperti :mudah panik, sulit bersantai, mudah marah, letih, dan lesu. Berdasarkan penelitian sebelumnya dan respon mahasiswa yang diwawancara, peneliti ingin mengetahui tingkat stres mahasiswa yang melakukan hailullah dengan mahasiswa yang tidak melakukan hailullah, dikarenakan kebanyakan mahasiswa memilih untuk tidur setelah subuh dibandingkan waktu malam, dan mereka merasakan hal-hal terkait stres setelah bangun dari hailulah.

\section{Metode Penelitian}

Jenis penelitian ini adalah penelitian eksperimental dengan desain penelitian menggunakan posttest only control group design. Kelompok dibagi menjadi dua, satu kelompok bertindak sebagai kelompok kontrol yang mendapat perlakuan tidur pagi. Satu kelompok bertindak sebagai kelompok eksperimental yang tidak mendapat perlakuan tidur pagi.

Penelitian dilakukan di Universitas Diponegoro, dari bulan Mei sampai bulan Agustus 2019. Teknik sampling yang digunakan adalah purposive sampling, peneliti 
PSISULA: Prosiding Berkala Psikologi

Vol. 1, 2019

E-ISSN: 2715-002X

menentukan kriteria subjek yaitu mahasiswa Universitas Diponegoro, rentang usia 18-22, dan memiliki kebiasaan tidur pagi. Mahasiswa yang bersedia menjadi subjek diminta mengisi google form yang disebarluaskan melalui media sosial berupa: line, whatsaap, dan instagram. Subjek yang medaftar melalui google form berjumlah 67 subjek. Langkah selanjutnya, subjek diminta mengisi informed consent sebagai bukti kesediaan menjadi sampel penelitian. Dari pengisian informed consent didapatkan 56 orang yang bersedia menjadi subjek penelitian ini. Kemudian dari 56 subjek tersebut dilakukan screening dengan pemberian pretest berupa skala DASS-21 kepada subjek. Tujuan pemberian screening adalah untuk menentukan kelompok yang menjadi kontrol dan kelompok yang menjadi eksperimen. Hasil pretest membagi rata 28 kelompok bertindak sebagai kontrol dan 28 kelompok bertindak sebagai eksperimen. Kemudian pada jangka waktu satu minggu, kelompok eksperimen diberikan perlakuan. Setelah selesai perlakuan, dilakukan pengukuran terhadap kedua kelompok. Perbandingan hasil antara dua kelompok menjadi menunjukkan efek dari perlakuan.

Penelitian ini menggunakan alat ukur skala DASS 21. The Depression, Anxiety and Stress Scale - 21 Items (DASS-21) adalah serangkaian skala yang dirancang untuk mengukur keadaan emosi depresi, kecemasan dan stres seseorang. Masingmasing dari tiga skala DASS-21 berisi 7 item, dibagi menjadi subskala dengan konten yang serupa. Sehingga total pernyataan yang diajukan kepada setiap responden adalah 21 pernyataan. Responden diminta untuk memilih sesuai kondisinya dengan poin 0 jika pernyataan sangat tidak sesuai dengan diri responden sepenuhnya, poin 1 jika pernyataan diterapkan pada responden sampai tingkat tertentu, atau pada suatu saat, poin 2 jika diterapkan responden untuk tingkat yang cukup besar atau sebagian waktu, dan poin 3 diterapkan responden sangat banyak atau sebagian besar waktu.

Skala depresi menilai disforia, keputusasaan, devaluasi kehidupan, penghinaan diri, kurangnya minat / keterlibatan, anhedonia dan inersia. Skala kecemasan menilai gairah otonom, efek otot rangka, situasional kecemasan, dan pengalaman subjektif dari pengaruh cemas. Skala stres sensitif terhadap tingkat 
PSISULA: Prosiding Berkala Psikologi

Vol. 1, 2019

E-ISSN: 2715-002X

gairah nonspesifik kronis. Skala stres ini menilai kesulitan bersantai, rangsangan gugup, dan mudah marah / gelisah, mudah marah / terlalu reaktif dan tidak sabar.

Setelah dilakukan perlakuan kepada kelompok eksperimen. Peneliti memberikan posttes kepada kedua kelompok. Kemudian didapatkan hasil posstest dari kelompok kontrol dan kelompok eksperimen. Hasil dari posttest tersebut kemudian dihitung menggunakan Mann-Whitney test.

\section{Hasil dan Pembahasan}

Penelitian ini menggunakan 56 orang subjek yang terbagi dalam 2 kelompok, satu kelompok kontrol dan satu kelompok eksperimen. Hasil dari penelitian tersebut adalah sebagai berikut:

Tabel 1. Nilai post test

\begin{tabular}{|c|c|c|c|c|}
\hline \multicolumn{5}{|c|}{ Ranks } \\
\hline & $\begin{array}{l}\text { Perlakuan responden saat } \\
\text { penelitian }\end{array}$ & $\mathrm{N}$ & Mean Rank & $\begin{array}{l}\text { Sum of } \\
\text { Ranks }\end{array}$ \\
\hline \multirow[t]{3}{*}{ Depresi } & Tidur & 28 & 30.48 & 853.50 \\
\hline & tidak tidur & 28 & 26.52 & 742.50 \\
\hline & Total & 56 & & \\
\hline \multirow[t]{3}{*}{ Kecemasan } & Tidur & 28 & 32.73 & 916.50 \\
\hline & tidak tidur & 28 & 24.27 & 679.50 \\
\hline & Total & 56 & & \\
\hline \multirow[t]{3}{*}{ Stres } & Tidur & 28 & 30.75 & 861.00 \\
\hline & tidak tidur & 28 & 26.25 & 735.00 \\
\hline & Total & 56 & & \\
\hline
\end{tabular}

Table 1 menunjukan bahwa semua nilai rata-rata subjek kontrol (yang melakukan hailulah) lebih tinggi daripada nilai rata-rata subjek eksperimen (yang tidak melakukan hailulah). Pada depresi, nilai rata-rata subjek kontrol adalah 30,48 dan nilai rata-rata subjek eksperimen adalah 26,52. Pada kecemasan, nilai rata-rata subjek kontrol adalah 32,73 dan nilai rata-rata subjek eksperimen adalah 24,27. Pada stres, nilai rata-rata subjek kontrol adalah 30,75 dan nilai rata-rata subjek eksperimen 26,25 . 
PSISULA: Prosiding Berkala Psikologi

Vol. 1, 2019

E-ISSN: 2715-002X

Penelitian ini menggunakan Mann-Whitney test dan hasilnya terlihat dalam tabel 2. Nilai signifikansi pada depresi adalah 0,359; kecemasan 0,050; dan stres 0,300 . Nilai signifikansi yang signifikan adalah $<0,05$, sehingga dapat disimpulkan bahwa hailulah (tidur pagi setelah salat subuh), berpengaruh secara signifikan terhadap penurunan tingkat kecemasan mahasiswa, dan tidak berpengaruh secara signifikan terhadap penurunan tingkat depresi dan stres mahasiswa.

Tabel 2 Tes statistik hasil post test

\begin{tabular}{lrrr}
\hline \multicolumn{4}{c}{ Test Statistics $^{\mathbf{a}}$} \\
\hline Depresi & Kecemasan & \multicolumn{1}{c}{ Stres } \\
\hline Mann-Whitney U & 336.500 & 273.500 & 329.000 \\
Wilcoxon W & 742.500 & 679.500 & 735.000 \\
Z & -.917 & -1.957 & -1.037 \\
Asymp. Sig. (2-tailed) & .359 & .050 & .300 \\
\hline
\end{tabular}

\section{A. Grouping Variable: perlakuan responden saat penelitian}

Penelitian ini menunjukkan bahwa mahasiswa yang memiliki kebiasaan tidur pagi memiliki tingkat kecemasan lebih tinggi daripada mahasiswa yang tidak melakukan kebiasaan tidur pagi setelah salat subuh. Selain itu, orang yang memiliki kebiasaan tidak tidur pagi memiliki tingkat depresi dan stres yang lebih rendah dibandingkan orang yang memiliki kebiasaan tidur pagi.

\section{Kesimpulan dan Saran}

Berdasarkan hasil yang didapat dari penelitian ini, menunjukkan bahwa tidak ada hubungan antara hailulah (tidur pagi setelah salat subuh) terhadap tingkat depresi mahasiswa, namun terdapat hubungan antara hailulah (tidur pagi setelah salat subuh) terhadap tingkat kecemasan dan stres mahasiswa berupa penurunan tingkat kecemasan dan stres pada subjek yang tidak melakukan hailulah. 
PSISULA: Prosiding Berkala Psikologi

Vol. 1, 2019

E-ISSN: 2715-002X

Peneliti mengharapkan penelitian ini dapat dilanjutkan, baik dengan variabel yang sama maupun berbeda dan hasilnya dapat diterapkan kepada masyarakat dalam kehidupan sehari-hari. Peneliti berharap penelitian selanjutnya dapat dikaitkan dengan bidang ilmu lain seperti pengaruh hailulah terhadap sistem endokrin atau pengaruh hailulah terhadap kebiasaan sarapan dan hubungannya dengan kecukupan kalori. Dalam penelitian selanjutnya, diharapkan dapat menggunakan jumlah subjek lebih banyak sehingga dapat lebih mewakili populasi. Selain itu, diharapkan juga menggunakan variabel kontrol yang lebih spesifik sehingga dihasilkan data yang lebih valid karena tidak dipengaruhi oleh faktorfaktor lain yang berbeda.

\section{Ucapan Terima Kasih}

Peneliti mengucapkan terima kasih sebesar-besarnya untuk kesempatan yang telah diberikan oleh Direktorat Kemahasiswaan, Direktorat Jenderal Pembelajaran dan kemahasiswaan, Kementerian Riset, Teknologi dan Pendidikan Tinggi kepada peneliti melalui pendanaan Program Kreativitas Mahasiswa Universitas Diponegoro tahun 2019 sehingga penelitian ini dapat terlaksana dengan baik.

\section{Daftar Pustaka}

Barr, F. D. and Harta, I. (2014) 'Analisis Manajemen Waktu Organisasi dan Kuliah Aktivis Mahasiswa Program Studi Pendidikan Matematika Universitas Muhammadiyah Surakarta', (2009), pp. 280-286.

Evanjeli, L. A. (2012) 'Hubungan Antara Stress, Somatisasi dan Kebahagiaan’.

Gaol NTL. 2016. Teori Stres: Stimulus, Respons, dan Transaksional. National Taiwwan Ocean University (NTOU).

Prabowo H. Arsitektur, Psikologi dan Masyarakat. Gunadarma. ISBN 9798382765.

Saffira P, Dahliana, Nurdin S. 2017. Upaya Manajemen Waktu dalam Mengatasi Stres Akademik Mahasiswa. Jurnal Ilmiah Mahasiswa Bimbingan dan Konseling. Vol 2, pp. 27-31 
PSISULA: Prosiding Berkala Psikologi

Vol. 1, 2019

E-ISSN: 2715-002X

Sarfriyanda, J., Karim, D. and Dewi, A. P. (2015) 'Hubungan Antara Kualitas Tidur Dan Kuantitas Tidur Dengan Prestasi Belajar Mahasiswa', Jurnal Online Mahasiswa Universitas Riau, 2(2), pp. 1178-1185.

Tuasikal, M A. 2015. Hukum Tidur Pagi Setelah Shubuh. Artikel Rumaysho.com

Zuama, S. N. (2014) 'Kemampuan Mengelola Stres Akademik Pada Mahasiswa Yang Sedang Skripsi Angkatan 2009 Program Studi Pg Paud', Jurnal Kreatif Tadulako, pp. 78-87. 